\title{
Nosocomial Clustering of Pandemic Influenza A (H1N1) Virus Infection as a Source of Fever in Patients with Hematological Malignancy
}

\author{
Saban ESEN ${ }^{1}$, Mahmut DULGER ${ }^{1}$, Ibrahim C. ACUNER ${ }^{2}$, Engin KELKITLI ${ }^{3}$, \\ M. Hilmi ATAY ${ }^{3}$, Hakan LEBLEBICIOGLU ${ }^{1}$ \\ ${ }^{1}$ Ondokuz Mayis University Faculty of Medicine, Department of Clinical Microbiology and Infectious Diseases \\ ${ }^{2}$ Ondokuz Mayis University Faculty of Medicine, Department of Clinical Microbiology \\ ${ }^{3}$ Ondokuz Mayis University Faculty of Medicine, Department of Haematology, Samsun, TURKEY
}

\begin{abstract}
Influenza related morbidity and mortality is higher in immunosuppressive patients. In this paper, four pandemic influenza cases have been described who had been hospitalized in a hematology and oncology unit. Three of the cases acquired pandemic influenza as a nosocomial infection. The sources of transmissions were an infected medical student in two of the cases. One of the cases acquired infection from a patient sharing the same room. All of the patients developed pneumonia and diagnosis of influenza was confirmed by PCR method. All of cases have been initiated to oseltamivir treatment. One of the patients died due to the uncontrolled primary disease. Oseltamivir use was terminated after five days of treatment in other cases. In patients hospitalized for the management of hematological malignancy, influenza should be considered in the differential diagnosis of neutropenic fever especially in the influenza season, and empirical antiviral therapy should be initiated in cases with influenza-like syndrome. To prevent nosocomial spread of influenza strict infection control strategies must be implemented.
\end{abstract}

Keywords: Influenza, Nosocomial infection, H1N1, Immunosupression

\section{ÖZET}

\section{Hematolojik Maligniteli Hastalarda Ateş Kaynağı Olarak Nozokomiyal Pandemik Grip (H1N1) Kümelenmesi}

Immunsupresif hastalığı olanlarda gribin mortalitesi ve morbiditesi yüksektir. Bu yazıda hematoloji servisinde takip edilen dört hastada gelişen pandemik grip (H1N1) olgusu sunulmuştur. Hastalardan üçüne gribin hastanede bulaştı̆ı belirlenmiştir. İki olguda kaynak, staj yapmakta olan tıp öğrencisi, diğerinde ise aynı odayı paylaştığı başka bir hastadır. Hastalara ampirik olarak oseltamivir tedavisi başlanmıştır. Dört olguda da pnömoni gelişmiş ve grip tanıSı PCR yöntemi ile doğrulanmıştır. Hastalardan biri tedavi altında iken primer hastalı̆̆ının kontrol altında olmamasına bağıı olarak kaybedilmiştir. Diğer hastalarda oseltamivir tedavisi beş güne tamamlanarak sonlandırımışıır. Hematolojik malignensinin yönetimi için hastaneye yatırlan hastalarda, nötropenik ateşin ayırt edici tanııında, özellikle influenza mevsiminde, influenza da düşünülmeli ve grip benzeri sendromu olan olgularda, ampirik olarak antiviral tedavi başlanmalıdır. Hastalara nozokomiyal grip bulaşını önlemek için gerekli sıkı infeksiyon kontrol önlemleri uygulanmalıdır.

Anahtar Kelimler: Grip, Nozokomiyal enfeksiyon, H1N1, Immunsupresyon 


\section{INTRODUCTION}

Nosocomially transmitted influenza may cause significant morbidity and mortality in the patients and healthcare workers at the hospital setting. Pandemic influenza caused by influenza virus type H1N1 rapidly spread in global biogeography after its first detection in the spring of 2009 , and continues to be a public health threat since then. Mortality rate in patients admitted to intensive care units due to pandemic influenza is approximately $15 \%$ while it is even higher in immunosuppressed patients. ${ }^{1.2}$ Immunosuppressed patients may spread the virus longer than other patients may. ${ }^{3}$ Influenza is an infectious disease transmitted mainly by droplet nuclei. In patients admitted to hospital with a preliminary diagnosis of influenza, respiratory hygiene/cough etiquette should be assigned immediately. Precautions for the containment of the spread of droplet nuclei such as spatial separation and source control measures (e.g. covering the mouth and nose with a tissue, using surgical masks) should be implemented. ${ }^{4}$ Patients with haematological malignancy are more susceptible to infections and the treatment of infections is more difficult. Thus, hospitalized patients with a preliminary diagnosis of influenza are placed in wards with isolation facilities. Hospitalization of such patients in haematology-oncology wards with immunosuppressed patients is avoided. In this study, we report the investigation of four cases with pandemic influenza (H1N1) of which three were nosocomial. To our knowledge, this is the first report of pandemic influenza (H1N1) cases occurred nosocomially in a haematology-oncology ward in Turkey.

\section{PATIENTS and METHODS}

Patients: The study involved patients hospitalized in a haematology-oncology ward with 52 beds. The study period was December 1, 2009 through December 31, 2009.

Case definitions: Case definitions described by Ministry of Health were used in the diagnosis of patients. 5 Therefore, definitions were as follows:

Probable case; An unexplained fever $\left(>38^{\circ} \mathrm{C}\right)$ associated with one of muscle pains, sore throat, headache, rinorrhea, coughing or shortness of breath.

Confirmed case; fulfilment of probable case definition criteria and detection or confirmation of the presence of pandemic influenza A virus type H1N1 with a laboratory test such as real-time PCR, viral culture or fourfold increase in the specific neutralizing antibody titer.
For the microbiological diagnosis of the patients, throat-swab specimens were collected in viral transport medium, and sent to the national influenza reference laboratory at Refik Saydam National Public Health Agency, Ankara. The method used in the reference laboratory for the confirmation of pandemic influenza A virus type H1N1 infection was real-time PCR. Demographic features (i.e. age and gender), underlying diseases, state of the underlying disease, vaccination state, laboratory findings and treatment regimens recorded in the probable cases. All patients received direct radiological examination. High-resolution computed tomography (HRCT) scanning was done in patients with detected infiltration in direct radiography. Complete blood count and neutrophil count were monitorized daily in the patients. Pandemic influenza vaccination state of the healthcare personnel of the affected ward was investigated. No samples were collected from the healthcare personnel for confirmatory influenza test.

\section{RESULTS}

Six of hospitalized patients with haematological malignancy were diagnosed as probable cases. In compliance with the definition of nosocomial infection, five of these patients developed influenza symptoms later than 48 hours of hospitalization. After specimen collection, patients were started on empirical oseltamivir treatment with a dosing regimen of $75 \mathrm{mg}$, twice daily for five days. Among the probable cases, four were defined as confirmed cases by PCR positive results. Demographic, clinical and laboratory findings of the confirmed cases were shown in Table 1.

Droplet and contact precautions were implemented for patients with probable case diagnosis. Oseltamivir therapy was completed to five days in all patients. Mechanical ventilation was needed in the first patient with confirmed case diagnosis. Other patients did not develop severe respiratory insufficiency. The source of nosocomial transmission was investigated in patients with confirmed diagnosis. Until the first patient was diagnosed as a probable case, the second patient shared the same room with the first patient. In the third and fourth patients, a medical student with symptoms of influenza was considered as the source of transmission. It was detected that the medical student had examined the third and fourth patient without employing appropriate safety precautions when he had symptoms of influenza. Besides, it was found that a healthcare worker had been entering the patients' rooms a few times daily although he had been receiving oseltamivir therapy with the diagnosis of 
Table 1. Demographic, clinical and laboratory findings of the confirmed pandemic influenza (H1N1) cases

\begin{tabular}{|c|c|c|c|c|}
\hline Patient Characteristics & Patient 1 & Patient 2 & Patient 3 & Patient 4 \\
\hline Gender & Male & Female & Female & Female \\
\hline Age & 59 & 35 & 31 & 57 \\
\hline Underlying Disease & $\begin{array}{l}\text { Haematological } \\
\text { malignancy? }\end{array}$ & Lymphoma & $\begin{array}{l}\text { Acute Myeloid } \\
\text { Leukaemia }\end{array}$ & $\begin{array}{l}\text { Non-Hodgkin } \\
\text { Lymphoma }\end{array}$ \\
\hline $\begin{array}{l}\text { Immunosuppressive } \\
\text { Therapy }\end{array}$ & $\begin{array}{l}\text { None } \\
\text { Corticosteroid }\end{array}$ & Chemotherapy & Chemotherapy & Chemotherapy \\
\hline Influenza Symptoms & $\begin{array}{l}\text { Fever } \\
\text { Cough } \\
\text { Shortness-of-breath }\end{array}$ & $\begin{array}{l}\text { Fever } \\
\text { Cough } \\
\text { Shortness-of-breath }\end{array}$ & $\begin{array}{l}\text { Fever } \\
\text { Cough } \\
\text { Rinorrhea }\end{array}$ & $\begin{array}{l}\text { Fever } \\
\text { Cough } \\
\text { Sore throat }\end{array}$ \\
\hline Confirmed Diagnoses & $\begin{array}{l}\text { H1N1 } \\
\text { Pneumonia } \\
\text { Endocarditis }\end{array}$ & $\begin{array}{l}\mathrm{H} 1 \mathrm{~N} 1 \\
\text { Pneumonia } \\
\mathrm{PCP}^{*}\end{array}$ & $\begin{array}{l}\text { H1N1 } \\
\text { Fungal Pulmonary } \\
\text { infection }\end{array}$ & $\begin{array}{l}\text { H1N1 } \\
\text { Pneumonia }\end{array}$ \\
\hline Neutrophil count/ $\mu \mathrm{L}$ & 6700 & 3700 & 7100 & 200 \\
\hline Lymphocyte count/uL & 700 & 200 & & 500 \\
\hline $\begin{array}{l}\text { Length-of-stay in Hospital } \\
\text { (days) before diagnose }\end{array}$ & New case & 13 & 35 & 5 \\
\hline Antiviral therapy & Oseltamivir & Oseltamivir & Oseltamivir & Oseltamivir \\
\hline Other Treatments & $\begin{array}{l}\text { Ceftriaxone } \\
\text { Vancomycin } \\
\text { Gentamicin }\end{array}$ & $\begin{array}{l}\text { Meropenem } \\
\text { Classic-amphotericin B } \\
\text { Teicoplanin } \\
\text { Co-trimoxazole }\end{array}$ & $\begin{array}{l}\text { Imipenem } \\
\text { Classic-amphotericin B }\end{array}$ & $\begin{array}{l}\text { Piperacillin-tazobactam } \\
\text { Vancomycin }\end{array}$ \\
\hline $\begin{array}{l}\text { Pulmonary Radiography } \\
\text { /HRCT Result }\end{array}$ & Bilateral infiltration & $\begin{array}{l}\text { Bilateral consolidation } \\
\text { in lower lobes }\end{array}$ & $\begin{array}{l}\text { Normal } \\
\text { Nodular infiltrations }\end{array}$ & $\begin{array}{l}\text { Bilateral diffuse } \\
\text { infiltration }\end{array}$ \\
\hline Outcome & Exitus & Recovered & Recovered & Recovered \\
\hline Ward/Room Number & Intensive Care Unit & Intensive Care Unit & $\begin{array}{l}\text { Haematology-oncology } \\
\text { /13- } 14\end{array}$ & $\begin{array}{l}\text { Haematology-oncology } \\
\quad / 14-15\end{array}$ \\
\hline $\begin{array}{l}\text { Probable Source } \\
\text { of Infection }\end{array}$ & Community- Acquired & $\begin{array}{l}\text { Sharing same room } \\
\text { with Patient } 1\end{array}$ & $\begin{array}{l}\text { Medical student with } \\
\text { influenza symptoms }\end{array}$ & $\begin{array}{l}\text { Medical student with } \\
\text { influenza symptoms }\end{array}$ \\
\hline $\begin{array}{l}\text { Vaccination Status } \\
\text { (i.e. H1N1 pandemic } \\
\text { influenza A virus vaccine) }\end{array}$ & None & None & None & None \\
\hline
\end{tabular}

influenza. Vaccination rate in affected unit physicians was $66 \%(4 / 6)$, while it was $37.5 \%(6 / 16)$ in nurses. The vaccination rate for medical students was $17 \%(1 / 6)$ in the unit.

\section{DISCUSSION}

This is the first study from Turkey that reports nosocomially clustered pandemic influenza infections in immunosuppressive patients. Influenza causes high morbidity and mortality in immunosuppressive patients. Influenza infection may or may not involve pulmonary tissue ${ }^{6,7}$ Fever in neutropenic patients is a severe condition that requires extended-spectrum antibiotic therapy. Antibiotic therapy should be started if a neutropenic patient develops fever over $38.3^{\circ} \mathrm{C}$ or lasting more than one hour at $38^{\circ} \mathrm{C} .{ }^{8}$ In case of fever developed under antibiotic therapy, either the antibiotic in use is changed or a new antibiotic is added to therapy. The most frequent symptoms of pandemic 
H1N1 influenza are fever associated with cough, sore throat, headache, nausea and vomiting. ${ }^{7}$ The underlying disease may mask the early findings of influenza. This may cause a delay in the diagnosis. The first patient in the cluster admitted to the hospital with the preliminary diagnoses of pneumonia and endocarditis and hospitalized in the intensive care unit. Among three patients with nosocomial pandemic influenza, one was continuing to be neutropenic. This patient was receiving antibiotic therapy with vancomycin in addition to previously started piperacillin-tazobactam. Just before the diagnosis of influenza, the other two patients had recovered from neutropenic state because of granulocyte colony-stimulating factor therapy. The fact that the diagnoses were confirmed in four out of six patients having influenza symptoms indicates the necessity of close monitoring of all symptoms in patients under risk. In haematological malignancy patients with influenza symptoms, early initiation of empirical therapy may be life-saving. ${ }^{6}$ In this cluster of patients, immediately after the emergence of symptoms and without waiting for the laboratory results, antiviral therapy initiated. In three of the nosocomially-affected patients, severe respiratory insufficiency did not develop. Fever returned to normal levels at 2nd, 6th and 3rd day of oseltamivir treatment, in patient two, three and four respectively. The patient who acquired the infection in the community setting died in the 3rd day of the antiviral therapy. This patient had severe pneumonia and echocardiographically supported diagnosis of endocarditis besides symptoms of influenza when admitted to the hospital. In two of the affected-patients, an unvaccinated medical student with symptoms of influenza was detected as the source of transmissions. In a ward where immunosuppressive patients hospitalized, all healthcare personnel including medical students should be vaccinated for influenza. In the haemotology-oncology ward, vaccination rates were low especially in the nurses. In a nosocomial outbreak of influenza, attack rate is found to be higher in patients than healthcare personnel and services of the affected internal medicine unit is disrupted. ${ }^{9}$ In a study investigating the epidemiology of influenza in leukaemia patients, visitors and healthcare personnel are shown to be the main source of transmissions..$^{10}$ Recently, outbreaks of oseltamivir-resistant strains occurring in immunosuppressive patients are reported from various regions of the world. ${ }^{3}$ In a study from United States of America, three of four cases are reported to be fatal although the exact role of pandemic (H1N1) influenza in the deaths of these patients is not known. These outbreaks indicate the necessity of strict compliance to infection control measures in units where immunosuppressive patients are hospitalized. It is reported that oseltamivir resistance may emerge in immunosuppressive patients under antiviral therapy. ${ }^{3}$ In one of the cases of nosocomial cluster, sharing the same room with another patient having pandemic influenza virus infection appears to be a risk factor for transmission. Environmental samples were not collected in the investigation of this clustering. Phylogenetic analysis and antiviral resistance assays of the influenza A viruses were not done in this study.

\section{Required Precautions in Preventing Nosocomial Transmission of Influenza to Immunosuppressive Patients}

When a patient with a main symptom of influenza such as coughing admitted to hospital, respiratory hygiene/cough etiquette should be assigned to the patient immediately, spatial separation should be implemented and covering of mouth and nose with a tissue or using a surgical mask should be done. If the patient needs to be hospitalized, conditions for droplet nuclei isolation should be employed. ${ }^{4}$ If an outbreak of influenza is suspected in a hospital unit, new patients should not be admitted to the unit without necessity. Immunosuppressive patients with influenza should be placed in single patient rooms if available. In case of a probable contact with the secretions of patient, healthcare personnel should wear gowns and gloves. Healthcare personnel when closer than one meter to patient should wear a surgical mask. Healthcare personnel should wear a respirator with a fitted N95 or FFP3 filtering during aerosol-generating procedures such as resuscitation, endotracheal intubation or suctioning of secretions. ${ }^{11}$ Patients should not be allowed to leave their rooms without an essential purpose. Whenever there is a necessity to transport the patient, a surgical mask should be provided. ${ }^{4}$ The number of healthcare personnel that may be exposed to the patient should be limited. Frequent displacement of the healthcare personnel should be avoided. Nasopharyngeal specimens should be collected from immunosuppressive patients having influenza symptoms, and the diagnosis should be confirmed. Visitors and caregivers should be informed about infection control measures. Visitors should be allowed only if necessary precautions were put in place. ${ }^{4,6,12}$ In research and training hospitals where students may contact patients, education should be given on isolation precautions, hand hygiene and infections in immunosuppressive patients. He- 
althcare personnel working in hospital units where immunosuppressive patients are hospitalized should be vaccinated. Healthcare personnel with influenzalike symptoms should be excluded from the care of neutropenic patients until the end of contagious period. If these healthcare personnel do not develop fever in 24 hours without using an antipyretic, they may return back to work. However, healthcare personnel who had contact with immunosuppressive patients should be re-examined. In this case, healthcare personnel may start working again after seven days from the emergence of symptoms or when influenza virus is not detected in their respiratory secretions. ${ }^{11}$ Persistence of cough does not mean that virus spread continues. ${ }^{11}$ In immunosuppressive patients who had contact with healthcare personnel or other patients having influenza, prophylactic oseltamivir or zanamivir therapy should be given. It should be kept in mind that resistance to drugs may emerge in immunosuppressive patients and infection with resistant-strain may quickly spread among patients. Through early diagnosis and therapy together with long-term isolation precautions, the spread of pandemic (H1N1) Influenza A virus infection may be prevented in neutropenic patients. Classically recommended isolation period in influenza cases is seven days consistent with the infectivity of the disease. However, it is shown that influenza virus may keep its activity longer than seven days in respiratory secretions of the patients..$^{13}$ Especially in immunosuppressive patients and young children this period may be longer., ${ }^{3,11}$ Therefore, infection control team and the physician should determine the length of isolation period individually for each patient.

\section{REFERENCES}

1. Kelly H, Grant K. Interim analysis of pandemic influenza (H1N1) 2009 in Australia: surveillance trends, age of infection and effectiveness of seasonal vaccination. Euro Surveill 14: 1-5, 2009.

2. Webb SA, Pettila V, Seppelt I, et al. Critical care services and 2009 H1N1 influenza in Australia and New Zealand. N Engl J Med 361: 1925-1934, 2009.

3. Englund J, Zerr D, Pergam S, et al. Oseltamivir-Resistant Novel Influenza A (H1N1) Virus Infection in Two Immunosuppressed Patients, Seattle, Washington, 2009. MMWR Morb Mortal Wkly Rep 58: 893-896, 2009.

4. Siegel JD, Rhinehart E, Jackson M, Chiarello L. 2007 Guideline for Isolation Precautions: Preventing Transmission of Infectious Agents in Health Care Settings. Am J Infect Control 35: 65-164, 2007.
5. http://www.grip.gov.tr/images/stories/pdf/ vakayonetimirehber.pdf (Access date: 26/01/2010) .

6. Kamboj M, Sepkowitz KA. Nosocomial infections in patients with cancer. Lancet Oncol 10: 589-597, 2009.

7. Thorner AR. Epidemiology of pandemic H1N1 influenza ('swine influenza'). In: UpToDate. Hirsch MS, McGovern BH (eds). Waltham, Massachusetts, 2010. (http://www.uptodate.com/contents/epidemiology-ofpandemic-h1n1-influenza-swine- influenza [Access date: 22.01.2010])

8. Hughes WT, Armstrong D, Bodey GP, et al. 2002 guidelines for the use of antimicrobial agents in neutropenic patients with cancer. Clin Infect Dis 34: 730$751,2002$.

9. Sartor C, Zandotti C, Romain F, et al. Disruption of services in an internal medicine unit due to a nosocomial influenza outbreak. Infect Control Hosp Epidemiol 23: 615-619, 2002.

10. Elting LS, Whimbey E, Lo W, et al. Epidemiology of infIuenza A virus infection in patients with acute or chronic leukemia. Support Care Cancer 3: 198-202, 1995.

11. http://www.cdc.gov/h1n1flu/guidelines_infection_control.htm. (Access date: 26/12/2010).

12. Meckler $\mathrm{G}$, Lindemulder $\mathrm{S}$. Fever and neutropenia in pediatric patients with cancer. Emerg Med Clin North Am 27: 525-544, 2009.

13. Leekha S, Zitterkopf NL, Espy MJ, et al. Duration of influenza A virus shedding in hospitalized patients and implications for infection control. Infect Control Hosp Epidemiol 28: 1071-1076, 2007.

\section{Correspondence}

Dr. Şaban ESEN

Ondokuz Mayıs Üniversitesi Tıp Fakültesi

Enfeksiyon Hastalıkları ve Klinik Mikrobiyoloji Bölümü SAMSUN / TURKEY

Tel: (+90.362) $3121919 \times 2736$

Fax: (+90.362) 4576041

e-mail: sabanes@omu.edu.tr 